\title{
Structure-Specific Endonucleases in DNA Repair
}

\author{
Orlando D. Schärer*
}

\begin{abstract}
Nucleotide excision repair (NER) is an essential DNA repair pathway that addresses a variety of DNA lesions formed by UV light, environmental mutagens and agents used in cancer chemotherapy. NER involves the concerted action of over 30 proteins and operates by the sequential assembly of the involved factors at sites of damage. NER culminates in the removal of an oligonucleotide containing the damage by two incision reactions 5' to the lesion by ERCC1-XPF and 3' to the lesion by XPG. ERCC1-XPF and XPG are structure-specific endonucleases, a large class of enzymes involved in a variety of DNA repair, recombination and replication pathways. This review focuses on some of our recent work on how the activities of the ERCC1-XPF and XPG proteins are regulated to incise DNA only at defined times during the NER pathway, thereby preventing the formation of unwanted and cytotoxic DNA breaks by random incision of DNA. The implications of this work for our understanding of endonuclease enzymology, carcinogenesis and anti-tumor therapy are discussed.
\end{abstract}

Keywords: Anti-tumor therapy · Cancer · DNA damage $\cdot$ DNA repair · Endonucleases

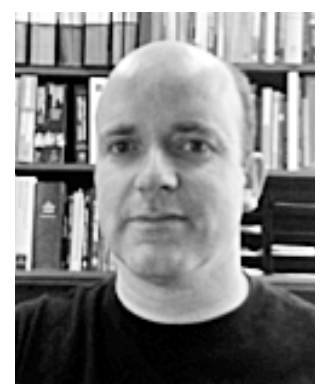

Orlando D. Schärer obtained his diploma in chemistry at the ETH Zürich in 1991 in the laboratory of Duilio Arigoni. He moved on to carry out his $\mathrm{PhD}$ thesis with Gregory Verdine at Harvard University, Cambridge, USA. In 1996 he joined the group of Roland Kanaar and Jan Hoeijmakers at Erasmus University, Rotterdam, Netherlands, for postdoctoral studies. In 1999 he began his independent career as START fellow of the Swiss National Science Foundation at the University of Zurich. In 2005, he moved to his present position as associate professor of pharmacological sciences and chemistry at Stony Brook University. His research interests involve the chemistry and biology of mammalian DNA repair and the relationship of these processes to carcinogenesis and anti-tumor therapy.

${ }^{\star}$ Correspondence: Prof. Dr. O. D. Schärer Stony Brook University

Departments of Pharmacological Sciences and

Chemistry

Stony Brook, NY11794-3400

Tel.: +1631632 7545

Fax: +16316327546

E-mail: orlando@pharm.stonybrook.edu

\section{Introduction}

DNA is an inherently reactive molecule and is constantly challenged by endogenous and exogenous agents that jeopardize the integrity of our genetic information. It has been estimated that each human cell is subjected to $10^{5}-10^{6}$ damaging events per day. [1] To prevent the deleterious consequences of DNA damage all organisms have evolved a number of elaborate systems to repair DNA. [2] The importance of DNA repair and the integrity of DNA are underscored by a number of inherited disorders resulting from defects in DNA repair genes that are associated with cancer and premature aging. A prototypical DNA repair disorder is xeroderma pigmentosum (XP). XP patients have a defect in the nucleotide excision repair (NER) pathway and are unable to repair UV lesions in their skin after exposure to sunlight. As a consequence, they suffer from extreme sensitivity to UV light, a more than 1,000-fold increased incidence of skin cancer and, in severe cases, neurological abnormalities. ${ }^{[3]}$

While diseases like XP underscore the importance of maintaining genome stability in healthy cells, DNA damaging agents have been used extensively in cancer chemotherapy. ${ }^{[4]}$ The inhibition of DNA repair is a desirable goal in a therapeutic setting, as it has been shown that DNA repair processes can contribute to the resistance of tumor cells to chemotherapeutic agents. ${ }^{[5]}$

Research in our laboratory is concerned with elucidating the detailed mechanisms of DNA repair pathways to understand i) how mutations in DNA and tumor formation are prevented and ii) how these pathways might be targeted for anti-tumor therapy. Here I will discuss our work in this area using the example of a key class of DNA repair enzymes, DNA endonucleases, which incise DNA during repair processes to remove of damaged sites from DNA.

\section{Structure-specific Endonucleases in DNA Repair}

The majority of DNA repair processes involve a step to cut the DNA at or near a lesion to remove damaged residues from DNA. ${ }^{[2]}$ This step is most often carried out by one of a large number of important endonucleases that cleave at a specific site in one or a limited number of pathways. Since DNA breaks (which may be formed by endonucleases as well as DNA damaging agents) are themselves cytotoxic DNA lesions, it is imperative that endonuclease activity is tightly regulated and limited to the appropriate DNA repair pathway. A common class of endonucleases cleaves specific DNA structures, ss/dsDNA junctions, which are common intermediates in DNA repair and recombination as well as in blocked replication forks. ${ }^{[6,7]}$ Such structure-specific endonucleases cleave DNA with defined polarities, cleaving either 5' ssDNA or 3' ssDNA overhangs. Multiple endonucleases exist that cleave overhangs with either orientation, emphasizing the need to specifically target these enzymes to the pathways in which they are involved. I will discuss how the action of two endonucleases, ERCC1-XPF and $\mathrm{XPG}$, is regulated in the nucleotide excision (NER) repair pathway. 


\section{ERCC1-XPF}

ERCC1 and XPF form a dimeric endonuclease that makes the incision 5' to a lesion in NER and, consistent with that polarity, has structure-specific endonuclease activity cutting ss/dsDNA junctions with 3' ssDNA overhangs (Fig. 1A). ${ }^{[8]}$ ERCC1 and XPF form an obligate heterodimer through interaction of two conserved helix-hairpinhelix domains at their N-termini and are unstable in each other's absence in cells. ${ }^{[9,10]}$ Work from our laboratory revealed that the active site of the heterodimer is contained within the XPF subunit of the protein.[11] Among a number of conserved acidic and basic residues, an $\mathrm{ERK}(\mathrm{X})_{3} \mathrm{D}$ sequence serves as a signature motif for this class of nucleases (Fig. 1A) that is also present in a number of other enzymes, including Mus81 (another endonuclease in the maintenance of genome stability). ${ }^{[12]}$

ERCC1-XPF contains multiple DNA binding domains. The N-terminal half of $\mathrm{XPF}$ is related to SF2 family of helicases, but has lost its ATP binding activity. ${ }^{[13]}$ The role of this domain is therefore likely to contribute to the binding of ss/dsDNA junctions, which are also intermediates in helicase-mediated reactions. The two Nterminal helix-hairpin-helix domains are typical DNA binding motifs ${ }^{[14]}$ and recent studies in our and other laboratories have shown that they contribute to DNA binding. $[10,15,16]$

In addition to its role in NER, ERCC1XPF is involved in at least two other DNA repair pathways, DNA interstrand crosslink repair and homologous recombination. The importance of these other roles are manifested in the phenotypes of a subset of patients and mice with deficiencies in ERCC1 and XPF, which include severely reduced life span and premature aging in addition to the classical XP symptoms. ${ }^{[17]}$ The recruitment of ERCC1-XPF to different pathways is regulated through proteinprotein interactions. We have recently established a structural and biochemical ba-

\section{A. ERCC1-XPF}
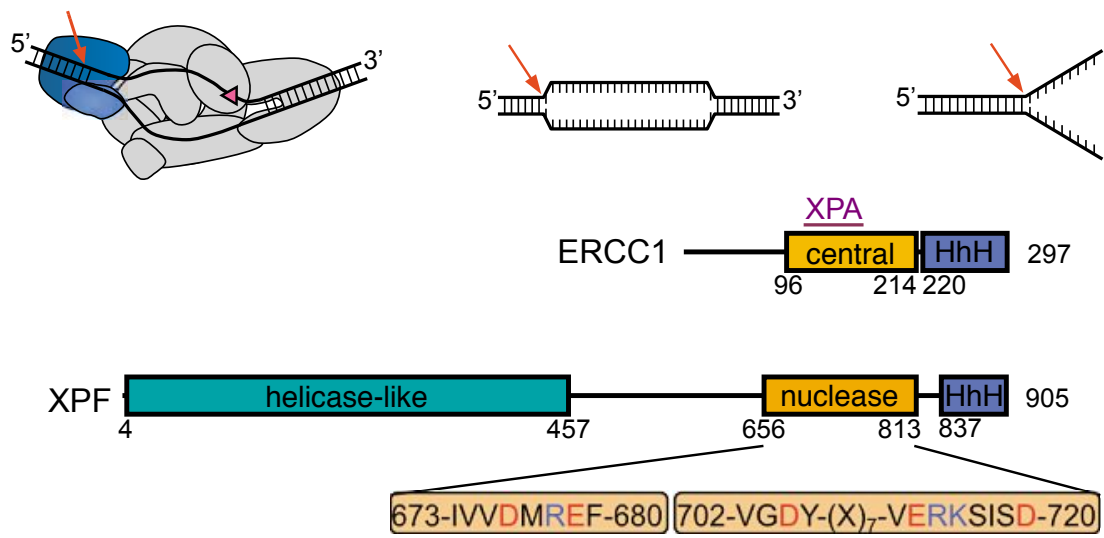

\section{B. XPG}
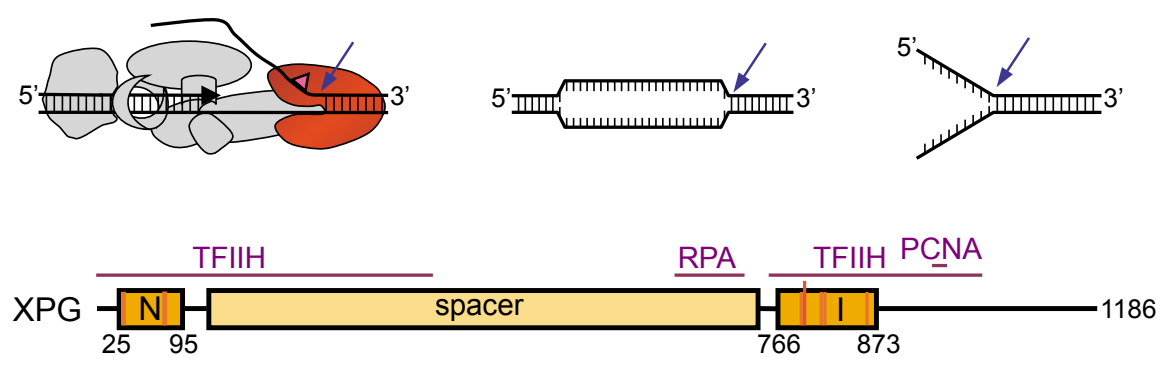

Fig. 1. Substrate specificity and primary structure of ERCC1-XPF and XPG. A. ERCC1-XPF makes the incision 5' to a lesion in NER and cleaves bubble and splayed arm substrates with 3' ssDNA overhangs. Cleavage sites are indicated by red arrows. ERCC1-XPF forms an obligate heterodimer through the helix-hairpin-helix regions (blue). Conserved acidic and basic residues of the nuclease active site domain are shown in red and blue, respectively. The central domain of ERCC1 that interacts the XPA protein and the helicase-like domain of XPF are indicated. B. XPG makes the incision 3' to a lesion in NER and cleaves bubble and splayed arm substrates with 5' ssDNA overhangs. Cleavage sites are indicated by blue arrows. The nuclease active site of XPG is made up of the $\mathrm{N}$ and I region (orange, acidic active site residues are indicated by red lines) and is separated by the 600 amino acid spacer region. Interaction sites for the TFIIH, RPA and PCNA proteins are shown. sis of how the interaction between the XPA protein and the central domain of ERCC1 targets ERCC1-XPF to sites of NER (see below), ${ }^{[18]}$ but much less is known about the interactions that are required for other pathways.

\section{XPG}

$\mathrm{XPG}$ is responsible for making the incision 3' to a lesion in NER and cleaves ss/dsDNA junction substrates with a polarity opposite to that of ERCC1-XPF (Fig. 1B) ${ }^{[19,20]}$ $\mathrm{XPG}$ is a member of the FEN1/XPG family of endonucleases and contains the signature $\mathrm{N}$ and I domains that make up the nuclease active site. ${ }^{[6,21]}$ The $\mathrm{N}$ and I domains in XPG are separated by a 600 amino acid insertion called the spacer region, whereas these two domains are much closer together in other FEN1/XPG family members. The spacer region is predicted to be highly disordered and is involved in protein-protein interaction as well in mediating XPG substrate specificity.[22,23]

As has been shown for ERCC1-XPF, XPG has roles outside of NER with the consequence that XPG deficiency can result in a much more severe phenotype in humans and mice that results from specific deficiency in NER. ${ }^{[24]}$ Interestingly, and in contrast to ERCC1-XPF, these additional roles of XPG are independent of its nuclease activity and mutations in XPG that result in specific nuclease deficiency result only in an XP-like phenotype. ${ }^{[25]}$ The more severe phenotypical manifestations of XPG mutations appear to be due to its association with the DNA repair and transcription factor TFIIH and a yet to be defined role in transcription. ${ }^{[26]}$

\section{The Nucleotide Excision Repair (NER) Pathway}

NER is the main pathway in mammals involved in the removal of lesions of environmental origin from DNA. A hallmark of NER is the extraordinarily broad substrate specificity, which includes adducts formed by UV light, environmental and food mutagens such as benz $[a]$ pyrene or acetylaminofluorene and antitumor agents such as cisplatin. [27] NER therefore appears to have evolved as an adaptable pathway able to deal with a wide variety of lesions that may result from a changing environment. Cell biological and biochemical studies have shown that NER operates through the coordinated and sequential assembly of the involved proteins at sites of the lesion and involves the following basic steps: damage recognition and opening of the DNA around the lesion, dual incision of the DNA releasing an oligonucleotide containing the lesion of 24-32 nucleotides in length, DNA polymerase-mediated fill- 


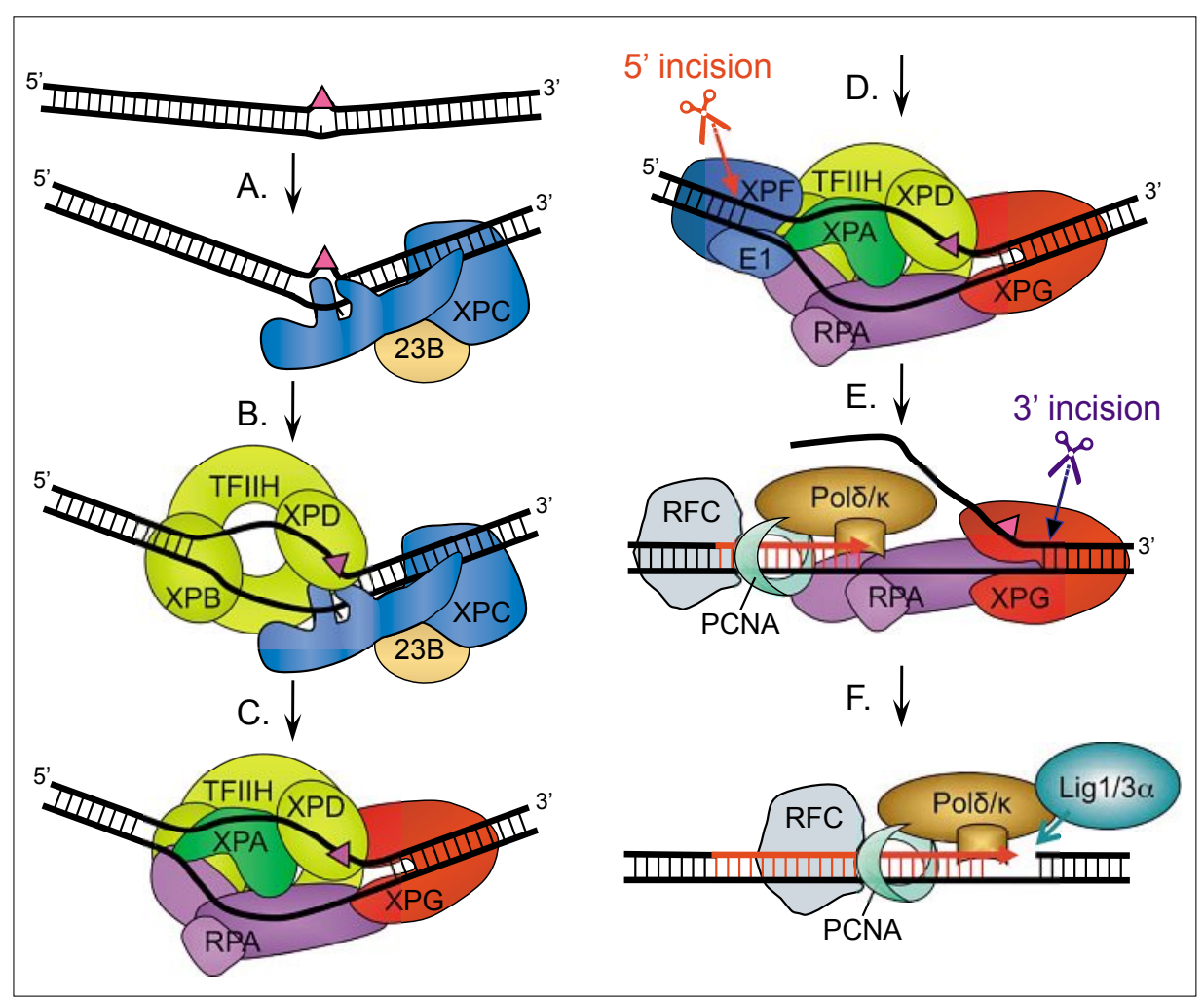

Fig. 2. The nucleotide excision repair (NER) pathway. A. Bulky DNA lesions recognized by XPCRAD23B (A). XPC-RAD23B binds to the undamaged strand of DNA, allowing for the recruitment of TFIIH (B) and the verification of the lesion by the XPD subunit. This allows the formation of the preincision complex by recruitment of XPA, RPA and XPG (C). Recruitment of ERCC1-XPF to the preincision complex through interaction with XPA leads to incision 5' to the lesion (D). The free 3'$\mathrm{OH}$ thus generated leads of the initiation of repair synthesis by Pol $\delta, \varepsilon, \kappa$ and associated factors (E), triggering 3' incision by XPG. Completion of repair synthesis and sealing of the nick by DNA Ligase $3 \alpha$ or DNA Ligase I completes the process (F).

ing in of the resulting gap and ligation of the nick.

\section{Damage Recognition and Verifica- tion by XPC-RAD23B and TFIIH}

NER is initiated by the XPC-RAD23B protein that has been shown to be required for the recruitment of all subsequent factors to sites of NER in vitro and in vivo. ${ }^{[28-31]}$ XPC-RAD23B binds specifically to helix-distorting lesions such as UV-induced 6-4-photoproducts (6-4PP), benz $[a]$ pyrene- and AAF-derived adducts (Fig. 2A). The repair of some less distorting DNA adducts, in particular UV-induced cyclopyrimidine dimers (CPDs), additionally involves the DDB1-DDB2 protein complex. ${ }^{[32]}$ Biochemical and structural studies have revealed that XPC-RAD23B binds sites in a duplex with single-stranded DNA character rather than a specific DNA lesion itself.[33,34] XPC-RAD23B also bind to thermodynamically destabilized sites such as base-base mismatches that do not contain chemical modifications. This lesionunspecific binding mechanism allows the protein to recognize a variety of structurally diverse lesions, but necessitates a step to verify the presence of a lesion since
NER only excises bulky lesions and not mismatches. ${ }^{[33,35]}$

It is widely believed that damage verification is accomplished by the next factor to be recruited to NER complexes, the ten subunit transcription/repair factor TFIIH. ${ }^{36]}$ TFIIH has two helicase subunits, XPB and XPD, which generate an open structure around the lesion (Fig. 2B). ${ }^{[28,37,38]}$ While the mechanism by which TFIIH operates in NER remains to be established, available data are consistent with a role for XPB in prying open the DNA around the lesion using its ATPase activity, ${ }^{[38,39]}$ allowing the XPD helicase to track along the DNA and separate the two strands until it is stalled when it encounters the lesion. Structural alterations such as mismatches that are bound by XPC-RAD23B but do not contain a chemical modification will not lead to a stalling of XPD leading to the disengagement of TFIIH and XPC-RAD23B. ${ }^{[40]}$

\section{Stable Preincision Complex Formation with XPA, RPA and XPG}

The immobilization of TFIIH facilitates the recruitment of XPA, RPA and XPG to sites of DNA damage leading to the formation of a relatively stable complex, which no longer includes XPC-RAD23B (Fig. 2C). ${ }^{[41]}$ XPA, once believed to be the initial damage recognition factor, preferentially interacts with non B-form structures that may mimic structural features of the NER preincision complex. ${ }^{[42]}$ XPA interacts with the ssDNA binding protein RPA, another factor of the preincision complex, with DNA structures arising as NER intermediates. ${ }^{[43]}$ RPA has many roles in DNA metabolism, notably in the replication of the lagging strand, and it has been shown that each RPA trimer covers a binding site of 30 nucleotides. ${ }^{[44]}$ The RPA binding site is therefore strikingly similar to the size of the excised fragment in NER. It is thus believed that RPA protein binds to the nondamaged strand of DNA in NER, where it helps to position the two endonucleases ERCC1-XPF and XPG. ${ }^{[45]}$

$\mathrm{XPG}$ is the first of the two endonucleases to arrive at NER complexes and is recruited by direct interaction with TFIIH. ${ }^{[23,46]}$ The first role of XPG in NER appears to be entirely structural: independently of the catalytic activity of the protein, it contributes to the stabilization of the preincision complex involving TFIIH, XPA, RPA and XPG (Fig. 2C). ${ }^{[41,47]}$ Although XPG incision activity has been observed in some instances at this point, the endonuclease activity is not likely to be revealed under physiological conditions (see below). ${ }^{[28,48]}$ Consistent with this notion, we have shown that XPG has distinct requirements for binding and cleaving DNA. ${ }^{[20]} \mathrm{We}$ interpret this to mean that a rearrangement of a domain in XPG has to occur for the catalytic activity to be revealed subsequent to DNA binding. A similar mechanism has been proposed for the XPG family member FEN1. ${ }^{[49]}$

\section{Recruitment of ERCC1-XPF by Interaction with XPA}

The last factor to join the preincision complex is the second endonuclease, ERCC1-XPF, and following its recruitment, the two incisions and repair synthesis are initiated. ${ }^{[30,31,41]}$ It has been established that an interaction between XPA and ERCC1 is necessary for NER and that this interaction involves three highly conserved glycine residues at positions $72-74 .{ }^{[50]}$ The region of XPA that interacts with ERCC1 is unstructured in the free protein. ${ }^{[16,51]}$ We have identified and characterized a small region in XPA that is necessary and sufficient for the interaction with ERCC1XPF to sites of NER through interaction with the central domain of ERCC1. ${ }^{[18]} \mathrm{A}$ 14 amino acid peptide encompassing residues 67-80 undergoes a disorder to order transition upon binding ERCC1 assuming a tight turn made up of the conserved gly- 


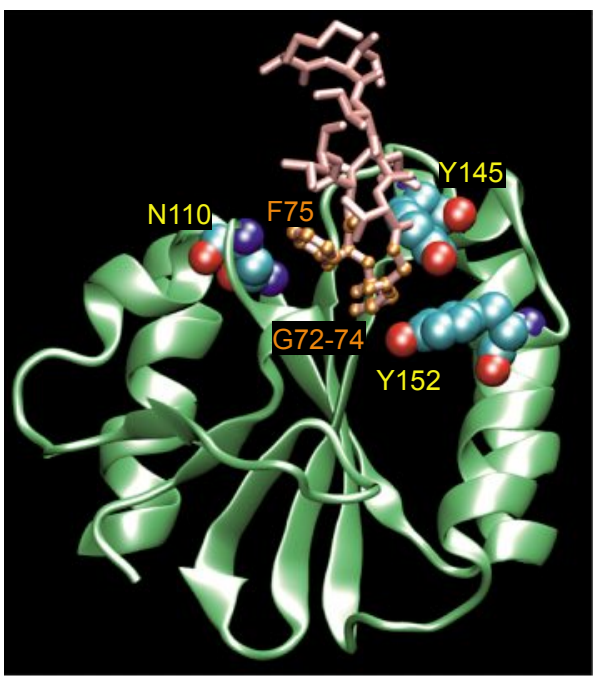

Fig. 3. Structure of an XPA peptide bound to the central domain of ERCC1. A peptide encompassing residues of XPA 67-80 (shown in pink) undergoes and disorder to order transition upon binding the central domain of ERCC1 (green). ${ }^{[18]}$ The interaction between XPA and ERCC1 is required for NER and residues at the interface that mediate the interactions are shown.

cines 72-74 (Fig. 3). A number of residues (N110, Y145 and Y145) in ERCC1 line the XPA binding pocket and pack against $\mathrm{G} 72$, G73, G74 and F75 residues in the XPA peptide. Mutation in these interacting residues in ERCC1 and XPA severely affect NER activity in vitro and in vivo. We found that the 14 amino acid peptide of XPA used in the structural studies was a specific inhibitor of NER, blocking the repair of cisplatin DNA adducts. ${ }^{[18]}$ A peptide in which the highly conserved F75 was mutated to an alanine failed to inhibit NER, indicat- ing that the inhibition of NER by the XPA peptide is highly specific. This work establishes that the interaction between ERCC1 and XPA might be targeted by small molecules to inhibit the repair of DNA adducts formed by cisplatin and related agents to increase efficiency of these agents in antitumor therapy.

\section{5' Incision by ERCC1-XPF Triggers DNA Incision and Repair Synthesis}

Once both endonucleases are in place, incisions 5' and 3' to the lesion by ERCC1$\mathrm{XPF}$ and XPG, respectively, take place. Following the removal of the damagecontaining oligonucleotide, the resulting gap is filled in by repair synthesis involving polymerases $\delta$ and $\kappa$, the clamp loader RFC, the processivity factor PCNA. ${ }^{[52]}$ Following the fill-in reaction, the nick in the DNA is sealed by XRCC1-DNA ligase $3 \alpha$ or DNA ligase 1 , thus completing the NER process. ${ }^{[53]}$

We reasoned that the two incisions should be tightly coordinated with each other and with repair synthesis to avoid the formation of unwanted long-lived ssDNA gaps. Consistent with this idea, it had previously been shown that the two incision events occur in a near simultaneous manner. ${ }^{[48,54]}$ Using catalytically inactive versions of ERCC1-XPF and XPG (XPFD676A and XPA-E791A), we and others have shown that 5 ' incision by XPF requires the presence, but not catalytic activity of XPG, while efficient 3' incision by XPG only occurs following 5 ' incision by XPF. $[37,47,55]$ Furthermore, we showed that repair synthesis can be initiated in the presence of catalytically inactive XPG in vitro,

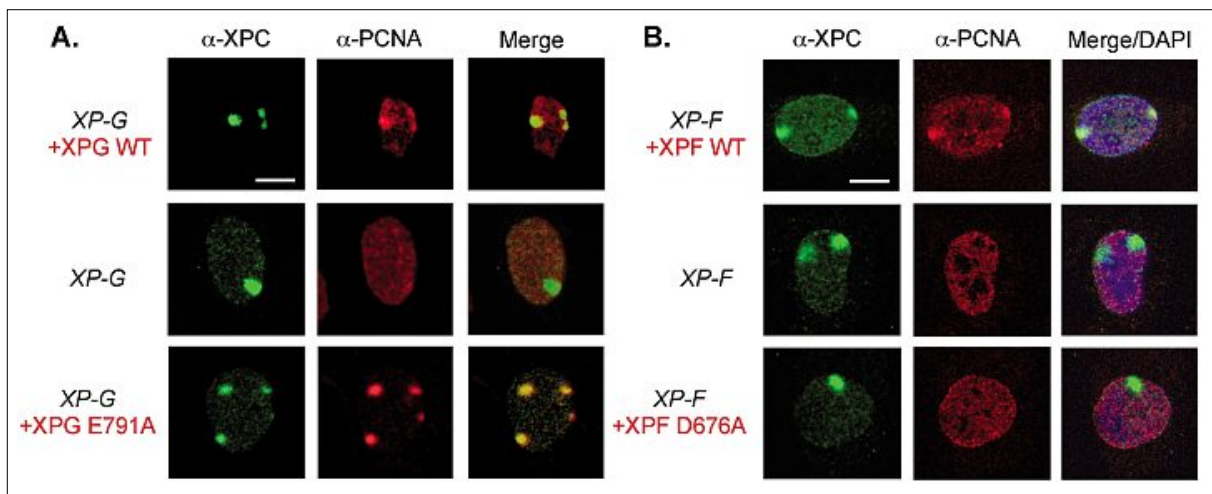

Fig. 4. Recruitment of the DNA repair synthesis machinery requires catalysis by ERCC1-XPF, but not XPG. XPG-deficient cells, untransduced or transduced with XPG-WT or XPG-E791A (A) and XPF-deficient cells, untransduced or transduced with XPF-WT or XPF-D676A (B), were grown on coverslips and locally irradiated with a UV dose of $150 \mathrm{~J} / \mathrm{m}^{2}$ through filters with $5 \mu \mathrm{m}$ pores and fixed 0.5 hours after irradiation. The cells were immunolabeled with antibodies against the damage recognition factor XPC (green) and replication factor PCNA (red). Merged images indicate the overlay of XPC, PCNA and the nucleus (DAPI staining). Note that XPC and PCNA colocalize in cells expressing XPG-E791A, but not in cells expressing XPF-D676A, indicating that the catalytic activity of XPF, but not XPG is required to recruit the replication machinery to sites of DNA damage. Scale bars, $10 \mu \mathrm{m}$. Reprinted with permission from ref. [55]. filling in about half of the gap (Fig. 2E). ${ }^{[55]}$ Cellular studies corroborated these biochemical findings. To study NER, cells can be irradiated with UV light through a polycarbonate filter with pores that are translucent to UV light. In this way a pattern of local UV irradiation can be established and the UV-damaged DNA and NER proteins recruited to the damaged DNA as part of the repair process can be detected using fluorescently labeled antibodies. ${ }^{[30]}$ In the context of the coordination of the dual incision and repair synthesis steps, we used this approach to show that the recruitment of the repair synthesis machinery to sites of NER (exemplified by PCNA, Fig. 4), required the presence and catalytic activity of XPF, but not 3' incision by XPG. These findings demonstrate that repair synthesis can occur prior to XPG incision, providing an important regulatory mechanism to avoid the formation of ssDNA gaps. We are now further investigating how the regulation of the dual incision and repair synthesis occurs. An additional possible key factor involved is RPA, which remains associated with the NER machinery well past the dual incision stage, possibly providing a platform for this transition. ${ }^{[31,56]}$ RPA is ideally suited to play this role, as it is believed that it is bound to the non-damaged complementary strand during NER and that it has a role in the repair synthesis step similar to its role in replication. ${ }^{[45]}$

\section{Conclusions}

Structure-specific endonucleases have essential roles in maintaining genome stability in a number of DNA repair pathways. The work from our and other laboratories described here provides insight into how two of these enzymes, ERCC1-XPF and XPG, operate in the nucleotide excision repair pathway. Through interaction with specific DNA structures and with other proteins, the activity of these enzymes is regulated such that they specifically cleave DNA as part of the NER pathway, avoiding the formation of aberrant DNA breaks that could threaten the integrity of DNA. This work has implications for the understanding of how the occurrence of mutations and carcinogenesis is avoided in healthy cells as well as for cancer chemotherapy. DNA repair pathways such as NER can lead to resistance of tumor cells to agents such as cisplatin that are extensively used in antitumor therapy.

\section{Acknowledgements}

I thank my coworkers, past and present, who contributed to our research on NER, in particular: Jacqueline Enzlin, Marcel Hohl, Ludovic Gillet, Lidija Staresincic, Jerome Gualbert, Barbara 
Orelli, Jung-Eun Yeo, Adebanke Fagbemi and Yan Su. Arthur Campbell is acknowledged for help with Figure 3. Work in the author's laboratory is supported by NIH grants GM080454, CA092584 and ES004068. The Swiss National Science Foundation, Swiss Cancer League, Human Frontiers Science Program Organization and New York State Office of Science and Technology and Academic Research (NYSTAR) are acknowledged for supporting our research on NER in the recent past.

Received: September 7, 2009

[1] E. C. Friedberg, G. C. Walker, W. Siede, R. D. Wood, R. A. Schultz, T. Ellenberger, 'DNA Repair and Mutagenesis', 2nd ed., ASM Press, Washington DC, 2005.

[2] O. D. Schärer, Angew. Chem. Int. Ed. 2003, 42, 2946.

[3] A. R. Lehmann, Biochimie 2003, 85, 1101.

[4] L. H. Hurley, Nat. Rev. Cancer 2002, 2, 188

[5] O. D. Schärer, Chembiochem 2005, 6, 27.

[6] M. R. Lieber, Bioessays 1997, 19, 233.

[7] A. Ciccia, N. McDonald, S. C. West, Annи. Rev. Biochem. 2008, 77, 259

[8] A. M. Sijbers, W. L. de Laat, R. R. Ariza, M. Biggerstaff, Y. F. Wei, J. G. Moggs, K. C. Carter, B. K. Shell, E. Evans, M. C. de Jong, S Rademakers, J. de Rooij, N. G. Jaspers, J. H. Hoeijmakers, R. D. Wood, Cell 1996, 86, 811.

[9] M. Biggerstaff, D. E. Szymkowski, R. D. Wood, Embo J. 1993, 12, 3685; A. J. van Vuuren, E. Appeldoorn, H. Odijk, A. Yasui, N. G. Jaspers, D. Bootsma, J. H. Hoeijmakers, Embo J. 1993 12, 3693; W. L. de Laat, A. M. Sijbers, H. Odijk, N. G. Jaspers, J. H. Hoeijmakers, Nucleic Acids Res. 1998, 26, 4146.

[10] O. V. Tsodikov, J. H. Enzlin, O. D. Schärer, T. Ellenberger, Proc. Natl. Acad. Sci. USA 2005, $102,11236$.

[11] J. H. Enzlin, O. D. Schärer, Embo J. 2002, 21, 2045

[12] L. Aravind, D. R. Walker, E. V. Koonin, Nucleic Acids Res. 1999, 27, 1223.

[13] J. Sgouros, P. H. Gaillard, R. D. Wood, Trends Biochem. Sci. 1999, 24, 95; T. Nishino, K. Komori, D. Tsuchiya, Y. Ishino, K. Morikawa, Structure (Camb) 2005, 13, 143 .

[14] A. J. Doherty, L. C. Serpell, C. P. Ponting, Nucleic Acids Res. 1996, 24, 2488.

[15] T. Nishino, K. Komori, Y. Ishino, K. Morikawa, Structure (Camb) 2003, 11, 445; M. Newman, J. Murray-Rust, J. Lally, J. Rudolf, A. Fadden, P. P. Knowles, M. F. White, N. Q. McDonald, Embo J. 2005, 24, 895; T. Nishino, K. Komori, Y. Ishino, K. Morikawa, Structure (Camb) 2005, 13, 1183; Y. Su, B. Orelli and O. D. Schärer, Stony Brook University, unpublished observations.

[16] K. Tripsianes, G. E. Folkers, C. Zheng, D. Das, J. S. Grinstead, R. Kaptein, R. Boelens, Nucleic Acids Res. 2007, 35, 5789 .

[17] J. McWhir, J. Selfridge, D. J. Harrison, S. Squires, D. W. Melton, Nat. Genet. 1993 5, 217; G. Weeda, I. Donker, J. de Wit, H Morreau, R. Janssens, C. J. Vissers, A. Nigg, H. van Steeg, D. Bootsma, J. H. J. Hoeijmakers, Curr. Biol. 1997, 7, 427; L. J. Niedernhofer, G. A. Garinis, A. Raams, A. S. Lalai, A R. Robinson, E. Appeldoorn, H. Odijk, R. Oostendorp, A. Ahmad, W. van Leeuwen, A F. Theil, W. Vermeulen, G. T. van der Horst, P. Meinecke, W. J. Kleijer, J. Vijg, N. G. Jaspers, J. H. Hoeijmakers, Nature 2006, 444, 1038 ; N. G. Jaspers, A. Raams, M. C. Silengo, N Wijgers, L. J. Niedernhofer, A. R. Robinson, G. Giglia-Mari, D. Hoogstraten, W. J. Kleijer, J. H. Hoeijmakers, W. Vermeulen, Am. J. Hum Genet. 2007, 80, 457.
[18] O. V. Tsodikov, D. Ivanov, B. Orelli, L. Staresincic, I. Shoshani, R. Oberman, O. D. Schärer, G. Wagner, T. Ellenberger, Embo J. 2007, 26, 4768; B. Orelli, B. McClendon, O. V. Tsodikov, T. Ellenberger, L. J. Niedernhofer, O. D. Schärer, Stony Brook University, submitted for publication.

[19] A. O'Donovan, A. A. Davies, J. G. Moggs, S. C. West, R. D. Wood, Nature 1994, 371, 432; E. Evans, J. Fellows, A. Coffer, R. D. Wood, Embo J. 1997, 16, 625 .

[20] M. Hohl, F. Thorel, S. G. Clarkson, O. D. Schärer, J. Biol. Chem. 2003, 278, 19500.

[21] D. Scherly, T. Nouspikel, J. Corlet, C. Ucla, A. Bairoch, S. G. Clarkson, Nature 1993, 363, 182.

[22] N. Iyer, M. S. Reagan, K. J. Wu, B. Canagarajah, E. C. Friedberg, Biochemistry 1996, 35, 2157; Z. $\mathrm{He}$, L. A. Henricksen, M. S. Wold, C. J. Ingles, Nature 1995, 374, 566; M. Hohl, I. DunandSauthier, L. Staresincic, P. Jaquier-Gubler, F. Thorel, M. Modesti, S. G. Clarkson, O. D. Schärer, Nucleic Acids Res. 2007, 35, 3053.

[23] I. Dunand-Sauthier, M. Hohl, F. Thorel, P. Jaquier-Gubler, S. G. Clarkson, O. D. Schärer, J. Biol. Chem. 2005, 280, 7030.

[24] O. D. Schärer, Adv. Exp. Med. Biol. 2008, 637, 83.

[25] T. Nouspikel, P. Lalle, S. A. Leadon, P. K. Cooper, S. G. Clarkson, Proc. Natl. Acad. Sci. USA 1997, 94, 3116.

[26] S. K. Lee, S. L. Yu, L. Prakash, S. Prakash, Cell 2002, 109, 823; S. Ito, I. Kuraoka, P. Chymkowitch, E. Compe, A. Takedachi, C. Ishigami, F. Coin, J. M. Egly, K. Tanaka, Mol. Cell 2007, 26, 231; O. D. Schärer, DNA Repair (Amst) 2008, 7, 339.

[27] L. C. Gillet, O. D. Schärer, Chem. Rev. 2006, $106,253$.

[28] E. Evans, J. G. Moggs, J. R. Hwang, J. M. Egly, R. D. Wood, Embo J. 1997, 16, 6559

[29] K. Sugasawa, J. M. Ng, C. Masutani, S. Iwai, P. J. van der Spek, A. P. Eker, F. Hanaoka, D. Bootsma, J. H. Hoeijmakers, Mol. Cell 1998, 2 , 223.

[30] M. Volker, M. J. Mone, P. Karmakar, A. van Hoffen, W. Schul, W. Vermeulen, J. H. Hoeijmakers, R. van Driel, A. A. van Zeeland, L. H. Mullenders, Mol. Cell 2001, 8, 213.

[31] T. Riedl, F. Hanaoka, J. M. Egly, Embo J. 2003, 22, 5293 .

[32] K. Sugasawa, Y. Okuda, M. Saijo, R. Nishi, N. Matsuda, G. Chu, T. Mori, S. Iwai, K. Tanaka, K. Tanaka, F. Hanaoka, Cell 2005, 121, 387; A. Scrima, R. Konickova, B. K. Czyzewski, Y. Kawasaki, P. D. Jeffrey, R. Groisman, Y. Nakatani, S. Iwai, N. P. Pavletich, N. H. Thoma, Cell 2008, 135, 1213.

[33] K. Sugasawa, T. Okamoto, Y. Shimizu, C. Masutani, S. Iwai, F. Hanaoka, Genes Dev. 2001, 15, 507.

[34] O. Maillard, S. Solyom, H. Naegeli, PLoS Biol. 2007, 5, e79; J. H. Min, N. P. Pavletich, Nature 2007, 449, 570; O. D. Schärer, Mol. Cell 2007, $28,184$.

[35] M. T. Hess, U. Schwitter, M. Petretta, B. Giese, H. Naegeli, Proc. Natl. Acad. Sci. USA 1997, 94, 6664 .

[36] R. D. Wood, Biochimie 1999, 81, 39; R. Dip, U. Camenisch, H. Naegeli, DNA Repair (Amst) 2004, 3, 1409.

[37] A. Tapias, J. Auriol, D. Forget, J. H. Enzlin, O. D. Schärer, F. Coin, B. Coulombe, J. M. Egly, J. Biol. Chem. 2004, 279, 19074.

[38] F. Coin, V. Oksenych, J. M. Egly, Mol. Cell 2007, 26, 245.

[39] L. Fan, A. S. Arvai, P. K. Cooper, S. Iwai, F. Hanaoka, J. A. Tainer, Mol. Cell 2006, 22, 27.

[40] S. C. Wolski, J. Kuper, P. Hanzelmann, J. J. Truglio, D. L. Croteau, B. Van Houten, C. Kisker, PLoS Biol. 2008, 6, e149; L. Fan, J. O. Fuss, Q. J. Cheng, A. S. Arvai, M. Hammel, V.
A. Roberts, P. K. Cooper, J. A. Tainer, Cell 2008 133, 789; H. Liu, J. Rudolf, K. A. Johnson, S. A. McMahon, M. Oke, L. Carter, A. M. McRobbie, S. E. Brown, J. H. Naismith, M. F. White, Cell 2008, $133,801$.

[41] M. Wakasugi, A. Sancar, Proc. Natl. Acad. Sci. USA 1998, 95, 6669 .

[42] M. Missura, T. Buterin, R. Hindges, U. Hübscher, J. Kasparkova, V. Brabec, H. Naegeli, Embo J. 2001, 20, 3554; U. Camenisch, R. Dip, S. B. Schumacher, B. Schuler, H. Naegeli, Nat. Struct. Mol. Biol. 2006, 13, 278.

[43] U. Schweizer, T. Hey, G. Lipps, G. Krauss, Nucleic Acids Res. 1999, 27, 3183; I. L. Hermanson-Miller, J. J. Turchi, Biochemistry 2002, 41, 2402.

[44] M. S. Wold, Annu. Rev. Biochem. 1997, 66, 61.

[45] W. L. de Laat, E. Appeldoorn, K. Sugasawa, E. Weterings, N. G. Jaspers, J. H. Hoeijmakers, Genes Dev. 1998, 12, 2598.

[46] S. J. Araujo, E. A. Nigg, R. D. Wood, Mol. Cell. Biol. 2001, 21, 2281; F. Thorel, A. Constantinou, I. Dunand-Sauthier, T. Nouspikel, P. Lalle, A. Raams, N. G. Jaspers, W. Vermeulen, M K. Shivji, R. D. Wood, S. G. Clarkson, Mol. Cell. Biol. 2004, 24, 10670; A. Zotter, M. S. Luijsterburg, D. O. Warmerdam, S. Ibrahim, A. Nigg, W. A. van Cappellen, J. H. Hoeijmakers, R. van Driel, W. Vermeulen, A. B. Houtsmuller, Mol. Cell. Biol. 2006, 26, 8868

[47] M. Wakasugi, J. T. Reardon, A. Sancar, J. Biol. Chem. 1997, 272, 16030; A. Constantinou, D Gunz, E. Evans, P. Lalle, P. A. Bates, R. D. Wood, S. G. Clarkson, J. Biol. Chem. 1999, 274, 5637.

[48] D. Mu, D. S. Hsu, A. Sancar, J. Biol. Chem. 1996, 271, 8285

[49] B. R. Chapados, D. J. Hosfield, S. Han, J. Qiu, B. Yelent, B. Shen, J. A. Tainer, Cell 2004, 116, 39.

[50] L. Li, S. J. Elledge, C. A. Peterson, E. S. Bales, R. J. Legerski, Proc. Natl. Acad. Sci. USA 1994. 91, 5012; L. Li, C. A. Peterson, X. Lu, R. J. Legerski, Mol. Cell. Biol. 1995, 15, 1993.

[51] G. W. Buchko, N. G. Isern, L. D. Spicer, M. A Kennedy, Mutat. Res. 2001, 486, 1.

[52] M. K. Shivji, V. N. Podust, U. Hubscher, R. D. Wood, Biochemistry 1995, 34, 5011; S. J. Araujo, F. Tirode, F. Coin, H. Pospiech, J. E. Syvaoja, M. Stucki, U. Hübscher, J. M. Egly, R. D. Wood, Genes Dev. 2000, 14, 349; T. Ogi, A. R. Lehmann, Nat. Cell. Biol. 2006, 8, 640.

[53] J. Moser, H. Kool, I. Giakzidis, K. Caldecott, L. H. Mullenders, M. I. Fousteri, Mol. Cell 2007, 27,311 .

[54] T. Matsunaga, D. Mu, C. H. Park, J. T. Reardon, A. Sancar, J. Biol. Chem. 1995, 270, 20862; J. G. Moggs, K. J. Yarema, J. M. Essigmann, R. D. Wood, J. Biol. Chem. 1996, 271, 7177.

[55] L. Staresincic, A. F. Fagbemi, J. H. Enzlin, A. M. Gourdin, N. Wijgers, I. Dunand-Sauthier, G. Giglia-Mari, S. G. Clarkson, W. Vermeulen, O. D. Schärer, Embo J. 2009, 28, 1111.

[56] V. Mocquet, J. P. Laine, T. Riedl, Z. Yajin, M. Y. Lee, J. M. Egly, Embo J. 2008, 27, 155. 